\title{
From Taiwanisation to De-sinification
}

Culture Construction in Taiwan since the 1990s

\section{Bi-yu Chang}

\section{(2) OpenEdition}

\section{Journals}

Electronic version

URL: http://journals.openedition.org/chinaperspectives/438

DOI: $10.4000 /$ chinaperspectives.438

ISSN: 1996-4617

\section{Publisher}

Centre d'étude français sur la Chine contemporaine

\section{Printed version}

Date of publication: 1 December 2004

ISSN: 2070-3449

\section{Electronic reference}

Bi-yu Chang, «From Taiwanisation to De-sinification », China Perspectives [Online], 56 | november december 2004, Online since 29 December 2008, connection on 28 October 2019. URL : http:// journals.openedition.org/chinaperspectives/438 ; DOI : 10.4000/chinaperspectives.438

This text was automatically generated on 28 October 2019 .

(C) All rights reserved 


\section{From Taiwanisation to De- sinification}

Culture Construction in Taiwan since the 1990s

\section{Bi-yu Chang}

1 On February 2nd 2004, less than fifty days before the 2004 presidential election, a reader's letter in the Lianhe bao (United Daily News) complained about the lack of cultural vision among the presidential candidates. The author examined the electoral campaigns of the two major parties: the Kuomintang (KMT) and the Democratic Progressive Party (DPP), and could find no party position on cultural policy. "Where is the future for Taiwan's culture?", he wrote, "Even rice wine and plastic bags have had a policy, where is our cultural policy?"1

2 As a matter of fact, cultural policy has always played an important role in Taiwanese politics. For example, the anti-communist principle and censorship were imposed in the 1950 s as a means to control cultural expression; the Cultural Renaissance Movement (Zhonghua wenhua fuxing yundong) was launched in 1967 as a counterattack response to the Cultural Revolution developing in mainland China; in 1977, Chiang Ching-kuo included culture in the Twelve National Construction Projects to respond to social change; in 1995, Lee Teng-hui supported the Community Construction Movement (shequ zongti yingzao), to further his political idea of the "community of shared fate" (shengming gongtong ti) ${ }^{2}$. Quite often, money was poured into projects, and measures were implemented, yet dissatisfaction with the direction that culture-building has taken continues ${ }^{3}$. But what is at the source of this criticism? Most usually the confusion arising from the question of how "culture" is to be defined, and expectations of what "cultural policy" should be.

A web of significance spun by the state

3 Many have taken "cultural policy" as something straightforward that everybody understands. Generally speaking, the term is used to denote "arts policy", or is described as referring to "a policy dealing with cultural affairs". ${ }^{4}$ Taking the anthropological point of view, "culture" encompasses almost everything. Whatever is distinctive about the way of life of a group of people, a community, a society, or a 
nation is culture. Therefore, to define cultural policy simply as arts policy seems overly narrow.

4 As the anthropologist Geertz has written, "man is an animal suspended in webs of significance he himself has spun, I take culture to be those webs, and the analysis of it to be therefore not an experimental science in search of law but an interpretive one in search of meaning." ${ }^{5}$ To follow Geertz, cultural policy can be seen as the webs that the state tries to spin in order to create such meaning. In other words, any official statement, policy and deliberate action/inaction with the intent to produce such types of meaning and formulate identity can be seen as a form of "cultural policy", the official indicator of the state's cultural blueprint. Hence, a broadly-defined "cultural policy" is not limited to cultural events, arts funding, arts education or cultural schemes, but also includes language policy, education policy, cultural movements and social policy that can create, as outcomes of such policy, cultural meaning ${ }^{6}$.

5 I am not suggesting that top-down policies have a direct influence on the way in which our sense of identity is constructed, or on the way we formulate our worldview. The political dimensions of cultural policy are usually hidden and therefore unseen. Framed within the Gramscian idea of "hegemony"7, cultural policy can be seen to be useful in disseminating and popularising a hegemonic discourse, useful in its turn in maintaining state power. Through regulating, funding, and encouraging selected art forms and artists, for example, cultural policy can help the state to create a favoured ideology, reinforce ruling-class-selected values, maintain control, increase cultural capital value, and thus ensure the success of this (cultural and political) "hegemony". Examination of such so-called cultural policies will reveal the kind of culture the state intents to build, and also help us understand how certain social and cultural changes came about.

The year 2000 marked the beginning of a new political era in Taiwan. However, did the course of national culture-building change accordingly? This article looks at how the political parties have constructed Taiwanese culture and identity since the 1990 s.

The beginning of Taiwanisation

7 For fifty years the KMT kept a tight grip on cultural expression in Taiwan. The "anticommunist literature and arts" (fangong wenyi) principle dominated the early post-war years, followed by a forceful sinification policy-the "Cultural Renaissance Movement" in the 1960s. This hit local culture very hard. The use of local dialects was forbidden in schools and public places ${ }^{9}$, Taiwanese traditional xiqu and folk arts were seen as crude and backward, and Taiwanese history was almost entirely absent from textbooks ${ }^{10}$. In other words, all things Chinese were associated with sophistication, beauty and grandeur, while all things Taiwanese were regarded as vulgar, stupid and coarse.

However, this sinification principle was severely shaken in the 1970s. There were many reasons for this change: the impact of international isolation, domestic demand for political reform, the end of the Cultural Revolution, and most of all, a cultural awakening in Taiwan. The KMT was forced to adopt a more localised and open approach. In 1977, Chiang Ching-kuo decided to include culture as one of the "national constructions", and in 1981, set up the Council for Cultural Affairs (CCA, wenhua jianshi weiyuanhui) in charge of Taiwan's cultural development. For the first time, indigenous culture and heritage were promoted alongside Chinese culture, even though a Chinacentric mentality still dominated the political scene. This changing course of cultural 
policy was not merely a political gesture, but a significant move shifting the cultural emphasis gradually from traditional China to contemporary Taiwan ${ }^{11}$.

In 1987, the lifting of martial law formally set off the process of indigenisation and democratisation. The emphasis in cultural policy shifted from traditional Chinese to contemporary Taiwanese. However, it was the rise of Lee Teng-hui that had the greatest influence in reconstructing Taiwan's political culture. Since the early 1990s, Lee started to openly promote Taiwanisation. For example, he reorganised the CCRC into a new cultural apparatus-the National Cultural Association (NCA, Wenhua zonghui) in $1991^{12}$, and advocated a "community of shared fate" to encourage the development of Taiwanese consciousness. He urged people in Taiwan, "For our future prosperity, we rely on one another. We are both Chinese and Taiwanese. There is no ethnic difference... We should be able to have an equal footing and equal opportunities." ${ }^{13}$ The starting point was "community"14.

In response, when the Ministry of Interior revised the Census Registration Law, the $z u j i^{15}$ (WW, ancestral origin) entry was abolished, and replaced with a record of one's "birthplace". Since then, the records of "second-generation mainlanders" have been officially removed. The ancestral differences between Taiwan-born baby-boomers became blurred. This change not only aimed to reduce shengji ${ }^{16}$ conflicts, but also demonstrated an official line defining the term "Taiwanese" to cut out unnecessary division.

When the KMT mainstream (zhuliupai), led by Lee Teng-hui, won the factional struggle in February 1993, the indigenisation trend finally gathered force and accelerated. Lee announced another slogan "Running Big Taiwan, Establishing the New Zhongyuan" (Jingying da Taiwan, jianli xin zhongyuan), in 1995, shifting Taiwan to the "central" position. He emphasised that his future state policy would "reinforce the superior status of Taiwan as the centre of new Zhongyuan"17.

In 1995, with Lee's involvement and support, the CCA launched the Community Construction Movement. It was designed by anthropologist Chen Chi-nan ${ }^{18}$, to be a mechanism to build Taiwanese consciousness and a new identity. Its ultimate goal was to encourage local people to care for their own environment, to make their own decisions, and to create community consciousness and a sense of belonging and pride. ${ }^{19}$ This policy has extended beyond the domain of arts policy, to create a "cultural vision"-construction of a "new homeland" (xin guxian) ${ }^{20}$.

13 All of a sudden, an originally political claim of "being one's own master and managing one's own affairs" (dangjia zuozhu) became a major concern in people's daily lives. Even with its shortcomings and the difficulties it encountered since its launch, the Community Construction Movement changed the infrastructure of Taiwanese society, cementing into it a sense of community, boosting Taiwanese awareness and constructing Taiwan as the "Homeland". Symbolically, this movement was the beginning of the official gesture to sever connections with the Chinese-centric identity that the KMT had promoted previously.

14 This increased local empowerment enhanced interest in Taiwanese culture and involvement in community affairs. In addition, the long-awaited education reform began around the same time. Education in Taiwan has always been conservative and slow to respond to social change, because it played a role as the final stronghold where the ruling power could construct ideologies and reproduce its values ${ }^{21}$. The KMT started both the standardised textbook system and nine-year compulsory education in 
1968 , in the attempt to control ideological construction. By imposing both systems at the same time, Taiwan's education after 1968 provided only one version of "the truth", and created a generation of Taiwanese who saw no other serious possible alternative to the economic and cultural assemblage then in place ${ }^{22}$.

The call for liberalisation in education began in the early 1980s, but change came late. It was not until 1996 that the standard textbook system was finally abolished in the elementary schools, and 1999 in junior and senior high schools ${ }^{23}$. Since then, Taiwanese teachers have finally been given the freedom to choose textbooks and have a say in how their teaching is conducted.

Even though the Ministry of Education (MOE) recognised the necessity to increase indigenous content in textbooks, it was slow to act. For example, the MOE had rejected several proposals to set up Taiwanese literature departments in universities. Soon after Lee Teng-hui won the first Presidential election in 1996, the tide turned.

In 1997, a new subject was added to the new junior high school curriculum: "Getting to Know Taiwan" (renshi Taiwan). However, it was attacked for being full of errors and over-politicised. Some criticised the content as selective and partial, some condemned the deliberate omission of Japanese colonial suppression, some identified an editorial prejudice against aborigines and women, and some suspected an attempt at desinification (qu Zhongguo hua) ${ }^{24}$. In spite of the controversy, the new subject was implemented. In the same year, the first Department of Taiwanese Literature was also approved at the Aletheia University (then Tanshui Management College). Since then, the MOE has not only approved the establishment of many Departments of Taiwanese Literature $^{25}$, but has also aggressively encouraged their development in order to cope with the pressing need to supply teachers to teach Local Studies (xiangtu jiaoxue), a new compulsory subject ${ }^{26}$.

18 After being forced to take on an indigenised stand in the 1980s, the KMT carried out Taiwanisation more aggressively and openly under Lee Teng-hui's lead. "Taiwanisation" was used by the KMT to gain support, renew its outdated image, and maintain cultural hegemony. Cultural policy in the 1990s, such as the Community Construction Movement, took up the role of promoting Taiwanese culture, fostering a sense of Taiwanese awareness, and promoting a new set of values.

The process of "Taiwanisation", which began in the 1980s and accelerated in the 1990s, altered the previously dominant China-centric identity, and created a new nationalpopular consensus. As a result, rebuilding a long-ignored indigenous culture became a common concern. The discourse of Taiwanese subjectivity was forming, and a new Taiwanese identity was emerging. Within only a few years, people's own perception of their identity changed dramatically ${ }^{27}$. By the late 1990s, the trend of Taiwanisation was accepted as politically correct. In accordance with Gramsci's idea of hegemony, the political regime change was achieved by a change of cultural hegemony. In 2000, the DPP won the Presidential election, because of what it represented-a Taiwanese awareness and subjectivity that had become increasingly popular. In contrast, this change of culture, being partially promoted by the KMT, ironically led to the KMT's downfall.

DPP culture construction

20 Since the DPP candidate Chen Shui-bian won the Presidential election in 2000, indigenisation has taken centre stage and become the DPP's top priority. An era of Taiwanisation finally got into full swing. However, facing the competition and impact 
of China hosting the 2008 International Olympic Games, the DPP launched the Challenge 2008-National Development Plan to increase Taiwan's international competitiveness ${ }^{28}$.

21 According to the Government Information Office (GIO) ${ }^{29}$, the "Challenge 2008" project is built around ten programmes, aiming to achieve significant political, financial and fiscal reforms. Substantial investments will be made in areas to improve manpower, R\&D and innovation, logistics networks, and the living environment.

According to the Council for Economic Planning and Development (CEPD) ${ }^{30}$, the aim of the scheme was to turn Taiwan into a "Green Silicon Island" (lüse xidao) ${ }^{31}$, aspiring to create a clean, high-tech and innovative island-state.

However, the scheme was severely hit soon after its launch, firstly by the impact made by September 11th incident on the world economy, and the uncertainty brought on by the war in Iraq, and secondly by the heavy blow dealt by the SARS epidemic in 2003. In order to boost the economy and renew the focus of Challenge 2008, less than two years later, the Executive Yuan announced Ten New Major Construction Projects in November 2003, expecting to invest NT $\$ 500$ billion in five years ${ }^{32}$. It is fair to say that Ten New Major Construction Projects are the cream of the Challenge 2008 project. This is an attempt designed to speed up the process of Challenge 2008 and ensure its completion ${ }^{33}$.

According to the GIO, the vision and aims of the projects are to: "strengthen Taiwan's international competitiveness and ensure that Taiwan keeps its number one position in Asia, and boost the drive to enter the global top three" (qianghua Taiwan guoji jingzhengli, quebao Yazhou di yi, jinjun shijie san qiang) ${ }^{34}$. It is obvious that the DPP government is aiming high. Stripping away the policy cliché and nationalist sentiment and ambition, the aim of the DPP was to make Taiwan ascend in the international arena as a world-class economic powerhouse, and a high-tech hub.

In keeping with the goal of turning Taiwan into a Green Silicon Island, the cultural emphases in these two national plans are placed on creativity, multicultural expression and domestic tourism. The ten new major construction plans clearly set up the task of building a Homeland in Taiwan, to construct a land of innovation and to preserve its natural beauty. However, the hidden agenda here is not just about becoming one of the global top three, but is in fact aimed at transforming Taiwan into a competitive, advanced, high-tech and culturally unique land, different in every way to China.

Three tendencies of the DPP culture construction

In comparing the cultural policy of the KMT and the DPP in the last two decades, it is clear that the former is more conservative and constantly struggling with its old nationalist baggage, while the latter celebrates Taiwanese-ness wholeheartedly and tries to create a new spiritual homeland. On the whole, the emphases on community construction and indigenisation remain unchanged between the two regimes. That said, the DPP cultural policy has three unique tendencies: an emphasis on the economic value of culture industries, the theorisation of Taiwanese subjectivity, and branding Taiwan as a cultural product. 


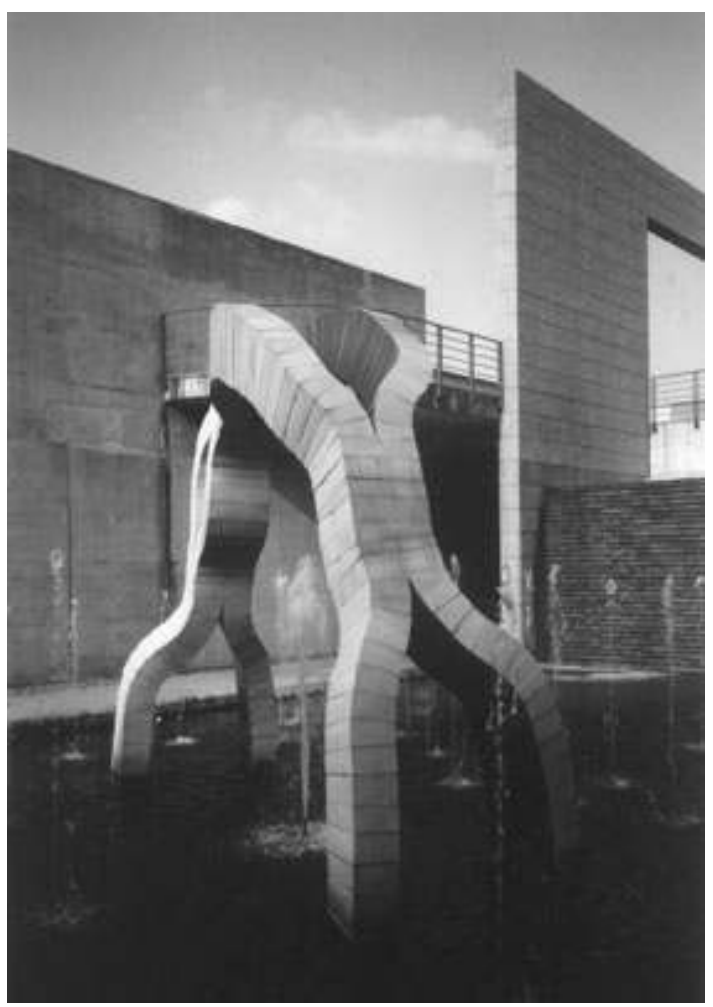

(c) Gilles Guiheux

\section{Emphasis on economic values}

Since the DPP came to power, it has forcefully advocated the economic value of the cultural and creative industries. Instead of concentrating on high culture as the KMT used to do, the DPP has shifted its focus to creative industries (including: design, tourism, popular music, film, fashion and digital industries), and stresses the added values they can bring. A new discourse has been created. By quoting the results of UNESCO research and taking European countries (especially the UK) as examples, the DPP proclaims that "culture is good business", emphasising the potential for employment and describing cultural industries as "sunrise/future-oriented industries" 35 .

As a matter of fact, this approach is not new in Taiwan. In 1996, the theme of the Community Construction Movement was "industrialising culture, and culturalising industry" (wenhua chanye hua, chanye wenhua hua), encouraging the marriage between local culture and industry (including agriculture, tourism, arts and crafts) ${ }^{36}$. However, the focus then was mainly on consolidating local communities and creating a sense of pride. Since 2000, this has shifted to boosting domestic tourism and stressing the economic benefits of culture. Consequently, instead of funding traditional categories in the arts, holding events, or promoting community construction, the DPP's cultural focus was more drawn towards how to increase its economic value.

Then CCA Chairwoman Tchen Yu-chiou ${ }^{37}$ (2000-2004) warned that the Community Construction Movement could not help Taiwan's traditional agricultural society cope with the impact of Taiwan entered the World Trade Organisation (WTO). Hence, a shift from "community building" to "local industry development" was necessary ${ }^{38}$. 
As a result, tourism becomes the major solution for combining local culture, natural resources, and commercial activities. Cultural tourism appears to provide all the answers: updating the social fabric of an agricultural society and transforming traditional farming practices into service-oriented industries. Furthermore, it provides the Taiwanese with opportunities to explore the unknown beauty of Taiwan, to consume cultural products and local delicacies, and to allow expression of affection towards one's homeland. For the DPP government, cultural tourism is a win-win policy -the Taiwanese learn to appreciate the long-ignored beauty of their homeland, and at the same time, their consumption also benefits local economies and regenerates depressed areas $^{39}$.

31 According to Tchen $\mathrm{Yu}$-chiou ${ }^{40}$, local culture should be the vehicle to improve tourism and increase employment opportunities. Such development would be, she believed, mutually beneficial for both urban and rural lives, and helpful for the revival of the local economy. Such remarks seem to suggest that the value of "culture" exists solely on its capability to "earn money" and "make contributions to the economy".

To help local industries modernise and transform into some form of cultural product, the CCA launched a "Local Culture House (difang wenhua guan) Programme" in 2002. This programme encouraged private investment in setting up local cultural houses for performances and exhibitions. Bringing together the artists, local historians, the tourism industry, agricultural industry, and town planning staff, the programme had a holistic approach.

Before the 1970s little recognition was given to local arts and culture

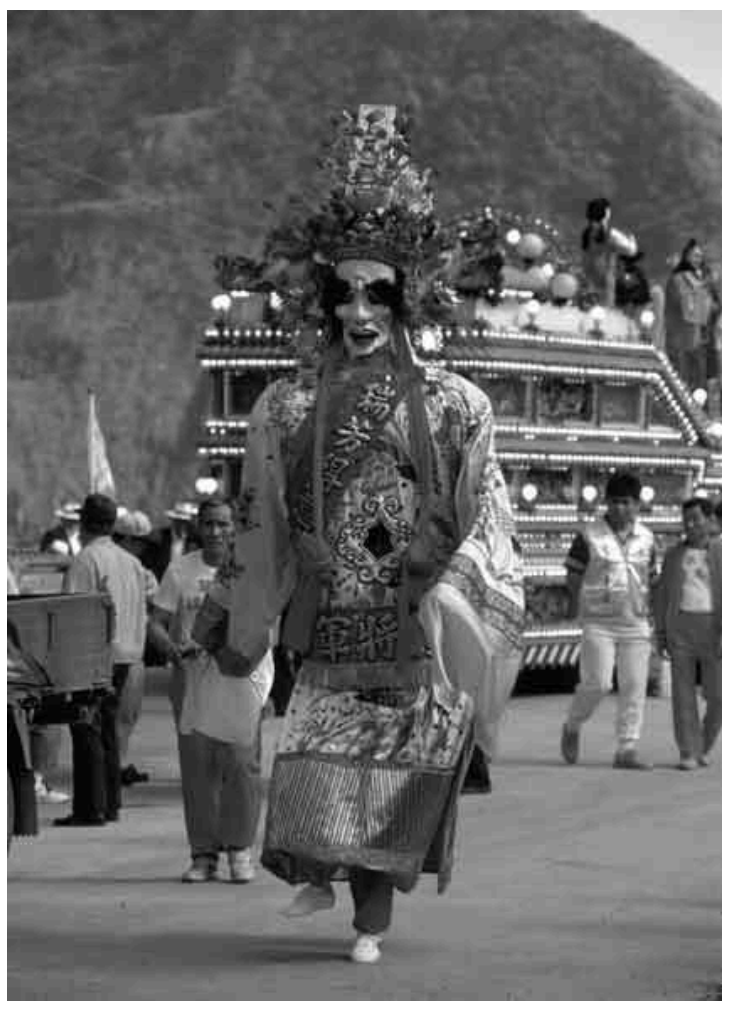

(c) Imaginechina

In the ten new major construction plans, most cultural investment was made in building art houses and culture centres ${ }^{41}$, and developing cultural tourism. However, 
the major emphasis of DPP cultural investment was placed on constructing buildings, not culture; and on creative industries, not creativity.

Furthermore, the DPP has repeatedly emphasised two issues: "culture" and "environment" in its national construction plans, setting the target of Green Silicon Island. The DPP government seems to be more concerned about environmental issues and cultural development, and hence, a more sophisticated and visionary government compared to the KMT with its constant emphasis on economic growth.

The ideal of building a "green island" seems, according to the national construction plans, to be the natural outcome of the industrial transformation of upgrading Taiwanese industries to a non-chimney industrial environment. Inevitably, tension grows between the wish to "preserve culture and natural resources" and the need to "develop the economy".

For example, the Water Resources Agency is considering building four artificial lakes island-wide to control flooding and ensure water supplies. Environmental groups are now protesting about the lack of environmental impact assessments. However, when the Legislative Yuan passed the Special Statute for Increasing Investment in Public Construction on June 11th 2004, this plan was expected to be the first to be carried out ${ }^{42}$ despite environmentalists' objections. It seems that when the economy is at stake, the ideal of building a green island can be easily sacrificed. In other words, the environmental issue is, for the DPP, second to economic growth.

Theorising Taiwan

Following Lee Teng-hui's openly promoted Taiwanisation, the KMT government began setting up research centres and museums ${ }^{43}$ to preserve Taiwanese culture and history, yet without relinquishing its China-centric position ${ }^{44}$. KMT culture construction seemed to be schizophrenic, being torn between public demands, the pressure from the opposition and the reactionary strains within the party. It pursued indigenisation on the one hand, while emphasising a China-centric ideology and Taiwan's cultural links with China on the other.

When the DPP came to power in 2000, a discourse of "Taiwanese subjectivity" had already grown. Through cultural policy, the DPP government became directly involved in the construction of "what Taiwanese culture was", introducing a Taiwan-centric worldview, restructuring the framework for the transmission of knowledge and redefining the meaning of "Taiwanese-ness".

In addition to constructing a homeland in Taiwan through tourism, the promotion of Taiwanese literature and the academic discipline of "Taiwan Studies" were crucial for the building of a "spiritual homeland". As Tchen Yu-chiou said, Taiwanese literature symbolised "a spiritual national territory", and the promotion of Taiwanese literature indicated a return of power to Taiwanese people to have their say about their own identity and "national narrative"

Furthermore, an effort to digitise Taiwan's historical archives has laid the foundations of "Taiwan Studies", and also ensured ready accessibility. The scale of these digitisation projects is astonishing. More than sixty digital archives projects have been initiated and are under construction ${ }^{46}$, and several virtual research centres also created ${ }^{47}$. Digital archives and databases not only provided valuable online resources for academic research, but also offered convenient teaching materials for "Local Studies" in schools. 
41 In order to encourage the development of Taiwan Studies as an acknowledged academic discipline, the funding given to academic research on Taiwan-related topics has risen dramatically. Furthermore, a large portion of foreign aid would also be diverted to scholarships for foreign students to study in Taiwan ${ }^{48}$. As DPP Premier Yu Shyi-kun suggested, such scholarships would provide many benefits, especially diplomatic ones. Yu predicted, Taiwan would be "forging an important link in the chain of Taiwan's long-term relations with foreign countries and serving to expand Taiwan's national power" 49 .

Domestically, the construction of a brand new spiritual national territory through education was also under way. Education could be very effective in constructing "a regime of truth" and a new identity. In 2001, a brand new education system, the Nine Grade Curriculum Alignment for Elementary and Junior High Education ${ }^{50}$, was launched, integrating the curriculum of elementary and junior-high schools.

"Getting to Know Taiwan" was removed from the new curriculum. Instead, the content covering Taiwan has been distributed across a range of subjects ${ }^{51}$. In other words, "Taiwan" has become the dominant theme of the new curriculum. Furthermore, the subject "Native Languages" (xiangtu yuyan) ${ }^{52}$ has been made compulsory in elementary schools from the third year upwards for one to two hours per week. It will only become optional when students reach junior high school level.

44 To link up with the Nine Grade Curriculum Alignment system, a new high school curriculum was also announced. The MOE claimed that this new curriculum endeavoured to remove politicised content and avoid ideological baggage. However, the new history curriculum was severely criticised specifically for being overpoliticised.

The disputes focused mainly on how the curriculum was structured, how history was taught, and what was taught. The new high school history curriculum proposed to draw a historical line in $1500^{53}$. The first year concentrates on domestic history, including Taiwanese history (prehistory to contemporary Taiwan) in the first term, and Ancient Chinese history (prehistory to the early Ming dynasty) in the second term. The theme of the second year is modern world history. Chinese history since 1500 including the latter part of the Ming dynasty, the entire Qing dynasty and the early history of the Republic of China (until 1949), was classified as part of contemporary world history.

The editorial guidelines for high school history textbooks-the "concentric circle" (tongxintuan) theory, proposed by historiographer Tu Cheng-sheng-were the same principles used for compiling "Getting to Know Taiwan". Tu interpreted this concept as "having its base on Taiwan, concerning China, and having a foot in the international arena" (lizu Taiwan, guanhuai Zhongguo, jinru shijie). This principle emphasised Taiwanese subjectivity, positioning Taiwan at the centre in order to understand its surrounding world and to interpret history. Tu claimed that the starting point of this view is "prioritising Taiwan" 54

Structuring history in such a way, the new curriculum was criticised for disseminating the idea of Taiwanese independence, and creating an ideological basis for a political goal: "one side one state" (yi bian yi guo) ${ }^{55}$. Dividing history at 1500 was condemned as a scheming way of cutting off the cultural umbilical cord with China, and constructing an independent historical subjectivity- "post-Ming Taiwan" ${ }^{56}$. Tu rejected speculation that his theory acted as a vehicle for de-sinification ${ }^{57}$. However, the debate continues and 
the new history curriculum is still in the process of consultation and modification. When Tu Cheng-sheng was appointed Minister of Education in May 2004, he announced that the new curriculum would be implemented as planned from the 2006 academic year ${ }^{58}$.

By building up a "spiritual national territory", encouraging Taiwan Studies and disseminating a Taiwan-central worldview, the DPP is reclaiming Taiwan's national territory. Alongside constitutional reform in the political sphere, the concept of "national territory" is also under reconstruction. The DPP's approach is "remapping Taiwan". Two series of maps of Taiwan were launched in 2003, and successfully challenged the conventional way of seeing Taiwan. The two series were: "Viewing Taiwan from Different Angles: Maps of Taiwanese Perspectives", and "Taiwan in Foreign Eyes: Maps of International Perspective".

The first series consisted of seven new maps, presenting unconventional approaches to mapping Taiwan's ethnic, oceanic, linguistic and cultural dimensions, and entitled: Our Eastern Asian Neighbours, Coming From Batan, From Tangshan to Taiwan, Taiwan's Assertion, My Austronesian Friends, Global Neighbours, Looking at Taiwan from the Seabed.

The second series consisted of 32 old maps selected from historical archives. They were chosen to demonstrate how Taiwan was viewed through foreign eyes over the past four hundred years, and to show Taiwan's maritime connections with the Dutch, the Spanish, the British and the Japanese.

51 As the CCA asserts, "Map... reflects the drawers' viewpoint and interpretation of a place, and hence, is a symbol of power... Through these [new] maps, Taiwanese subjectivity... is clearly shown, providing opportunities for Taiwanese to understand their homeland and plan for the future" ${ }^{59}$. These two series demonstrated Taiwan's international position, showing links with its Asian neighbours and connections with the world since the sixteenth century. The significance of these maps showed that Taiwan's relationship with China is only a small part of Taiwan's past.

52 Thus it appears that the DPP government has tried to release Taiwan from the previous discourse of "Taiwan being part of China". Mapping Taiwan is another way of asserting Taiwanese subjectivity and articulating a national narrative. In other words, the CCA's attempt to re-map Taiwan is a redefinition of Taiwan's "national territory".

53 Furthermore, the DPP has, since coming to power, taken many measures to express a more Taiwan-centric position with the intention of creating cultural meaning and changing people's values. For example, wording in the new passport has changed ${ }^{60}$; the issuing bank and the design of new banknotes were changed ${ }^{61}$; the discourse about the origin of Taiwanese aborigines has been reconstructed ${ }^{62}$; a plan to relocate capital from Taipei to Kaohsiung was aired ${ }^{63}$; national holidays are frequently changed ${ }^{64}$. All these contributed to reframing a new national narrative, generating an independent identity, creating a different worldview, and fading out the shadow of Chinese influence.

Branding Taiwan

Believing that culture is economically beneficial, the CCA joined forces with the Industrial Development Bureau (Ministry of Economic Affairs) to encourage the development of creative industries, funding modern designs to present Taiwanese culture. In a speech about future CCA policy, then chairwoman Tchen Yu-chiou openly asserted that "using branding techniques to build and introduce an image of 
contemporary Taiwan to the world, cultural and creative industries will be the most important force." 65

The CCA took the initiative to organise competitions and give funding, in order to encourage the growth of creative industries, and establish a unique and innovative brand name for Taiwanese products. For example, the "2003 Taiwanese Fashion Party" encouraged Taiwanese designers to introduce indigenous culture into their fashion designs and to use local textiles. According to the Taiwan Journal, an official journal published by the GIO in English, this scheme aimed to create a Taiwanese "national costume ... [that] reflects its cultural essence and acts as a touchstone to its national identity"

The "Searching for Taiwan Red" (xunzhao Taiwan hong) project was another example of using culture to "brand Taiwan". The scheme was set up to find a colour that represented Taiwan's cultural image in the international society, giving a "uniformed" corporate look, and increased commercial opportunities for Taiwan's cultural products and industries. As Tchen Yu-chiou explained at the launch of Taiwan Red, "Turkey has its turquoise, Taiwan should also have its own colour" ${ }^{67}$. A shade of dusty pink was chosen, because of its association with traditional culture, festivals and celebrations. It was said that Taiwan Red was like the red of the red rice cake (hongguike). This colour, according to Tchen, represents "the joy of Taiwan", showing a country with a positive, modern and joyful image, shaking off the sad and bleak old past ${ }^{68}$.

When the exhibition "The Earth From Above" by French photographer Yann ArthusBertrand was shown in Taiwan, the CCA negotiated a deal with his workshop to include Taiwan in his next project Visages et Paysages. Then CCA chairwoman Tchen Yu-chiou has high hopes for this project and hopes this opportunity will "let the world see Taiwan and get to understand us better"69.

Indeed, "let the world see Taiwan" is the ultimate goal for "branding Taiwan". For example, the CCA has aggressively promoted 12 potential sites to be accepted by the UNESCO as a World Heritage site ${ }^{70}$, with the same purpose-let the world see Taiwan ${ }^{71}$. Similarly, the plans to hold the Taiwan Exposition in 2008, the Taiwanese Arts Exposition in 2005, and the 2009 World Games share the aim of showing off Taiwan's economic achievement, creativity and cultural development.

The desire to "make ourselves known" has been deeply embedded among the Taiwanese since the 1970 s diplomatic defeats. As Taylor ${ }^{72}$ rightly says, the recognition of the "significant others" is crucial for the formation of identity. To gain recognition, it is crucial to create dialogical relations with others ${ }^{73}$. Over the years, although formal diplomatic relations were developed through much hard work, Taiwan has tried to participate actively in international organisations and has endeavoured to build informal diplomatic relations. In order to break through the PRC diplomatic blockade and avoid direct conflict, "culture" has always been the "dialogue" that creates and articulates an "ideal identity" to the significant others.

60 A new "brand association" of Taiwan is under construction, using marketing strategy, invented tradition and innovative ideas. It is an interesting tactic taking cultural policy as a marketing tool to brand a country. In other words, despite the seemingly apparent emphasis on indigenisation and building a homeland, deep down, the DPP cultural policy is motivated by a desire to promote Taiwan in international society as a new cultural state. Instead of promoting Taiwanese artists performing "traditional Chinese arts" on the international stage, as the KMT did, the DPP has strived to find new ways 
of "narrating" Taiwan. Among all cultural influences in Taiwan, aboriginal culture was identified as the best asset in creating a non-Chinese image and to "sell" Taiwan".

61 Since 2000, the DPP has carried out culture construction on a grand scale. As described above, the DPP has worked to build a discourse of Taiwanese subjectivity by reaching out at every possible level, from school to community, from commercial behaviour to academic activities.

In the past, the KMT used cultural exchange as a means to expand diplomatic relationships. The DPP has taken this further. Taiwan is presented as a cultural product, placed on the international market by the creation of brand names, logos, positioning, brand associations, and brand personality. Taiwan is marketed by the DPP as a place of rich natural beauty and cultural heritage, it has a distinct colour, a highly developed computer industry, and is filled with theatres of international standard. Branding Taiwan articulates an ideal identity and a new version of a national narrative to significant players internationally. By going global, the DPP aims to renew Taiwan's international image, and cut cultural ties with China.

Since the 1990s, the similarities between the cultural policies of the two parties are striking. Both the DPP and the KMT have promised to develop culture, promote community construction, encourage multi-cultural development, and preserve heritage. They have both advocated the establishment of a Ministry of Culture and Tourism ${ }^{75}$. However, the DPP has been more creative and forceful. The major differences between the two parties are mainly their priorities.

The KMT had used Taiwanisation to hold on to its political power and had managed to maintain its cultural hegemony for almost two decades. Although preserving Chinese culture was not as important as developing Taiwanese culture by the end of the 1990s, the KMT government had never given up the cultural link with China. In contrast, the aim of DPP Taiwanisation was de-sinification. It emphasised the unique mixture of Taiwan's hybrid culture, and embraced the discourse of Taiwanese subjectivity ${ }^{76}$.

In 2004, Chen Shui-bian won the presidential election, and the ideological dominance of the DPP has been confirmed and secured. Taiwanisation has formally become a national-popular consensus. After Chen's victory, there have been several interesting cabinet appointments. Anthropologist Chen Chi-nan, the architect of the Community Construction Movement, was appointed as CCA chairman in charge of culture construction. His appointment shows the DPP's continued emphasis on building a new homeland. Historiographer Tu Cheng-sheng was appointed Education Minister. His appointment indicates a further de-sinification of knowledge transmission; Tchen Yuchiou, former CCA chairwoman and a DPP veteran, was appointed as a National Policy Consultant in the Presidential Office and a cultural ambassador. Because of her past performance in marketing Taiwan, her appointment also represents a more aggressive approach to branding Taiwan.

66 The new cabinet arrangements confirm the DPP's culture construction strategybuilding Taiwan's brand name internationally, constructing a contemporary hybrid culture in Taiwan, and theorising and transmitting a DPP-versioned national narrative.

Even if the KMT had won the 2004 election, according to their White Paper for Culture, their emphasis on Taiwanisation would have definitely continued, promoting digital industry, sport and leisure activities. In contrast, the DPP continues its focus on the construction of community culture, and endeavours to sever Chinese influence. As a 
young and emerging state, or at least a de facto political entity, the DPP government has strived to present Taiwan as an island state in its own right, rather than being taken as a Chinese off-shore island, or a reference point to China. The aim is simple: to reduce the Chinese claim on Taiwanese culture and political ownership.

\section{NOTES}

1. Lu Lu, "Even Rice Wine Has a Policy, Where is Cultural Policy?", United Daily News, February $2^{\text {nd }} 2004$. The DPP did not have a clear cultural policy for the 2004 Presidential election campaign, the KMT announced its White Paper on Culture on February $20^{\text {th }}$. In contrast, both parties issued their White Papers on Culture for the 2000 presidential election.

2. Lee Teng-hui proposed that people in Taiwan should consolidate as "one community", emphasising the shared fate and common interests of its people. Lee Teng-hui, Jingying da Taiwan (Managing Big Taiwan), new edition, Taipei, Yuanliu, 1995, p.106.

3. For example, Chu Hui-liang, "Wo guo wenhua zhengci zong jiantao" (Examining Taiwan's Cultural Policy), National Policy Foundation (NPF) research report, Internet Edition, available at http://www.npf.org.tw/PUBLICATION/EC/093/EC-R-093-001.htm, February $10^{\text {th }}$ 2004; Li Yih-yuan, Wenhua de tuxiang (Portraying Culture), Taipei, Yunchen, $2^{\text {nd }}$ ed., 1996; Han Pao-teh, "What Kind of Ministry of Culture We Need?",. Independent Evening News, November $5^{\text {th }} 1989$.

4. Dimaggio P., "Cultural Policy Studies: What They Are and Why We Need Them", The Journal of Arts Management and Law, Vol. 13, No. 1, Spring 1983, pp. 241-248; Lewis J. , "Designing a Cultural Policy", The Journal of Arts Management, Law and Society, Vol. 24, No. 1, Spring 1994, pp. 41-56.

5. Geertz Clifford, The Interpretation of Cultures, London, Fontana Press, 1973, p. 5.

6. For example, policies that: change national holidays, street and town names, add the word "Taiwan" to passport covers, change how the census is recorded.

7. Gramsci Antonio, Selections from Prison Notebooks, edited and translated by Quintin Hoare \& Geoffrey N. Smith, London, Lawrence \& Wishart, 1971.

8. The Cultural Renaissance Movement was the KMT's attempt to establish its political legitimacy through culture. During ten years of Cultural Revolution in a China closed to the rest of the world, Taiwan successfully provided an alternative, and supplement to traditional China. People in Taiwan were constantly told to believe that the ROC on Taiwan was more Chinese than China. Ku Feng-hsiang, "Twenty Years of Cultural Renaissance Movement", Zhongyang ribao, Central Daily News, July $28^{\text {th }} 1987$.

9. In 1966, the provincial government announced the Reinforcement Programme on Mandarin Promotion (Jiaqiang tuixing guoyu jihua). Those found using local dialects in school, even in private conversation, were humiliated and fined. Although local dialects were still used privately or at home, this promotion plan had created a sense of shame and degradation among Taiwanese for using their own languages. Chen Mei-jun, "Taiwan zhanhou yuyan kecheng yu jiaoxue yanbian qushi zhi yanjiu" (Studies on 
Curriculum and Changes of Language Teaching in Post-war Taiwan), Taipei, National Taiwan Normal University, PhD thesis, 1996.

10. Before the 1990s, Taiwan as a subject had always been ignored in Taiwanese textbooks. Taking the "Chinese History" (Benguo shi, 1983 edition) textbooks as an example, the average appearance of Taiwan was less than $5 \%$ throughout the six-year period of secondary education. Moreover, the focus of this brief coverage was mostly placed on Taiwan's post-war "development". Liu Hsiao-fen, "Wo guo Zhongguo lishi jiaokeshu zhong Taiwan shi jiaocun de fenxi" (Analysis of the Textbooks in Taiwan's History Education [at Secondary Education]), Taipei, National Chengchi University, MA thesis, 1991, p. 107.

11. Chiang Ching-kuo set up the CCA to sideline the Chinese Culture Restoration Committee (CRCC, Zhonghua wenhua fuxing yundong weiyuanhui). It was clear that he intended to replace "cultural renaissance" with "cultural development". When Chiang Ching-kuo was elected as ROC President in 1978, he declined to follow the precedent set up by his father, and followed by Yen Chia-kan, to hold the CCRC presidency. It indicated the decline of CCRC influence and political support.

12. In 1991, Lee Teng-hui replaced the CCRC with the NCA, and became its president. Before Lee Teng-hui's political power was stabilised, the NCA constantly played the role as Lee's mouthpiece to explain and elaborate his political ideas.

13. Lee Teng-hui, "Guojia jianshi yanjiu ban di yi qi shici" (Speech to the First Nationbuilding Research Group), June $10^{\text {th }} 1994$, Internet version.

14. Lee Teng-hui, Jingying da Taiwan, op. cit., pp. 106- 107.

15. In the old census registration, a mainlander who came from Quanzhou after 1945 would have his/her zuji recorded as "Quanzhou City, Fujian Province". However, residents who lived in Taiwan before 1945, even though their ancestors might come from Quanzhou, would have their zuji recorded as "Taiwan".

16. Shengji literally means "the province of one's birthplace or origin". According to Wachman, people in Taiwan generally categorised themselves, according to their shengji, as aborigines, Taiwanese (including Minnan and Hakka) or mainlanders. Ethnologically, Taiwan's Austronesian people were the original inhabitants of the island. By December 2003, there were 444,823 Austronesians, making up $1.968 \%$ of the total population $(22,604,550)$. The category 'Taiwanese' in this context refers to Han Chinese who (or whose parents) lived in Taiwan prior to the 1940s migration. The category of mainlander refers to Chinese who came to Taiwan after 1945. Therefore, the division of shengji in Taiwan refers not only to origins, but also to the time of arrival on the island. Alan M. Wachman, Taiwan: National Identity and Democratisation, M.E. Sharpe, 1994, p.17; The Department of Household Registration Affairs, the Ministry of Interior, "Zhonghua minguo Tai Min diqu zhongyao renkou zhibiao" (Important Population Indexes in Taiwan and Fujian Regions, ROC), June $8^{\text {th }} 2004$.

17. The symbolic meaning of Zhongyuan was not limited to a geographical notion, but had more to do with its central cultural position and the significance of political legitimacy. Lee Teng-hui claimed that a new Zhongyuan culture had formed in Taiwan after the Second World War. The slogan not only manifested Lee's intention to build Taiwan as the centre of a new culture, but also demonstrated his wish to build Taiwan as a spiritual homeland, to outgrow and divorce itself from the motherland that had previously been imposed on it. Lee Teng-hui, Jingying da Taiwan, op. cit., p. 11; "Lee Teng-hui xiansheng bashisi nian yanlun ji” (Collective Speeches of Lee Teng-hui in 1995), Taipei, GIO, 1996, pp.11-19. 
18. Chen was recommended to Lee Teng-hui in the early 1990 s to advise on cultural issues. He was appointed the Deputy Chairman of the CCA to launch the Community Construction Movement (1994-96). In May 2004, he was appointed CCA chairman. 19. Wenhua baipi (White Paper on Cultural Affairs), Taipei, CCA. 1998, p. 85.

20. Chen Chi-nan, "Xin guxiang yundong, chong xian taohua yuan" (New Homeland Movement Re-Establishes the Land of Peach Blossom), United Daily News, February $18^{\text {th }}$ 1996.

21. Apple Michael, Ideology and Curriculum, London, Boston and Henley, Routledge \& Kegan Paul, 1979, pp. 26 -30.

22. Ibid, p.6.

23. In 1989, the system started to loosen, and allowed publishers to compile some textbooks. However, textbooks for traditional academic subjects (such as Chinese, Mathematics, History, and Geography) and subjects concerning ideology-building (such as Social Studies, Citizenship) were still collectively provided by the National Institute for Compilation and Translation.

24. Wang Chung-fu, Wei lishi liuxia jianzheng: "renshi Taiwan" jiaoke shu cankao wenjian xinbian (Witness History: Collective Documents About "Getting to Know Taiwan" Textbooks), Taipei, Strait Academic Publisher, 2001.

25. There were: the National Cheng Kung University, National Ching Hua University, Providence University, and many normal universities.

26. The Ministry of Education (MOE) started to set up the optional module "Local Studies" in 1993. However, it was made compulsory only in 2001. Weng Tsui-ping, “State-Run Universities will Set Up Taiwanese Literature Department in 2002", Central News Agency, January $17^{\text {th }} 2001$.

27. In 1992, the majority of people in Taiwan still considered themselves "Chinese" (44\%) or "both Taiwanese and Chinese" (36.5\%). Only 16.7\% claimed that they were purely "Taiwanese". This situation started to reverse between 1994 and 1996. The figures of those who identified themselves as "Chinese" kept on falling (21.7\% in 1994, $23.8 \%$ in $1995,20.5 \%$ in $1996,23.1 \%$ in $1997,18.7 \%$ in $1998,13.1 \%$ in 1999 , and $13.6 \%$ in $2000)$ and those identifying themselves as "Taiwanese" continued to grow (28.4\% in $1994,27.9 \%$ in $1995,24.9 \%$ in $1996,36.9 \%$ in $1997,37.8 \%$ in $1998,44.8 \%$ in $1999,42.5 \%$ in 2000). The group that saw themselves as "both Taiwanese and Chinese" became the majority. Taipei: Mainland Affairs Council, How People in Taiwan Identify Themselves, 2000 January, (Internet Version), Available at http://www.mac.gov.tw/big5/mlpolicy/pos/ 9001/table12.htm

28. CEPD, Challenge 2008 -- National Development Plan, Internet edition, May $31^{\text {st }} 2002$.

29. GIO, Ten New Major Construction Projects, Internet edition, 2003.

30. CEPD, Challenge 2008, 2002.

31. Tchen Yu-chiou, “Taiwan wenhua xin siwei” (New Thoughts on Taiwanese Culture), Internet edition, speech in the Industrial Technology Research, February $27^{\text {th }} 2004$.

32. CEPD, Ten New Major Construction Projects, Internet edition, February $10^{\text {th }} 2004$.

33. Personal communication with the CEPD (at webserv@my.cepd.gov.tw), $30^{\text {th }}$ March 2004.

34. GIO, Ten New Major Construction Projects, 2003.

35. CCA, "Origin of the Project", The Development Plan for Cultural and Creative Industries, (Internet Edition), 2003.

36. Chen Chi-nan, Shequ zongti yingzao yu shengcheng xuexi (The Community

Construction and Life-Long Learning), Taipei, CCA, 1996. 
37. Tchen Yu-chiou, "Difang wenhua guan de zhengce yu shijian" (The Policy and Practice of Local Culture), Difang wenhua guan tongxun jikan (Local Culture House Quarterly), December 2002, Vol. 1, p. 1.

38. CCA, "Origin of the Project", 2003.

39. CCA, Difang wenhua guan jihua (Local Culture House Programme), September 10th 2002.

40. Tchen Yu-chiou, "The Policy and Practice of Local Culture House", 2002.

41. The DPP was keen to build cultural facilities and boasted of their "international" standard. Construction plans include: a new Taipei Metropolitan Opera House (Panchiao); the southern branch of the National Palace Museum; the transformation of military-owned barracks into Weiwuying Arts Centre (Kaohsiung); and a new Austronesian Cultural Park (Taitung). Even the negotiations are in deadlock, the plan to build the Guggenheim Museum in Taichung is still listed as one of the major construction plans.

42. "Artificial Lakes Get Attention of Ecology Groups", Taipei Times, (Internet Edition), June $21^{\text {st }} 2004$.

43. There are plenty such examples that were set up in the late 1990s but opened after 2000, including the preparatory offices of the National Centre for Traditional Arts (set up in 1996), the Traditional Music Research Institute (1999), the National Museum of Taiwanese Literature (1997) and the National Cultural Heritage Preservation and Research Centre (1997).

44. Lee's decision to rescue Taiwan's Peking opera was a good example. The Ministry of National Defence (MND) had been the authority responsible for the preservation and performance of Peking opera since 1949. Under pressure from the opposition, the MND decided to dissolve all three Peking opera groups in November 1994. It was a sensitive pre-election period, and the objections within the KMT alarmed Lee Teng-hui. Advised by then Secretary-General to President Chiang Yen-shih, Lee overturned the dissolution proposal. Instead, he instructed chiang to rescue the plan by entrusting the MOE with the task of setting up a national Peking opera group.

45. "National Museum of Taiwanese Literature is Formally Opened", Tainan City Government newsletter, October $17^{\text {th }} 2003$.

46. Involved institutions include: the Academia Sinica, the CCA, the Academia Historica, National Museum of Nature and Science, National Palace Museum, National Taiwan University, Taiwan Literature Museum, and National Central Library.

47. For example, the Japanese Government-General in Taiwan archive, the "Taiwan History and Culture in Time and Space" and the "Database of Native Geographical Names in Taiwan Region".

48. A total of NT $\$ 80$ million (US $\$ 2.4$ million) will be provided to choose at least 200 foreign students each year. The programme is expected to run for tenars and will gradually grow to fund 400 foreign students receiving more than NT $\$ 140$ million each year. "Government Tries to Lure Foreign Students with Cash", Taipei Times, Internet edition, June $7^{\text {th }} 2004$.

49. GIO, "Yu Calls for Scholarships for Foreigners to Study in Taiwan". GIO newsletter, December $2^{\text {nd }} 2003$.

50. Chang Shu-fang, "Tan guomin jiaoyu jiu nian yiguan kecheng fazhan » (The Development of the Nine Grade Curriculum Alignment for Elementary and Junior High Education), Zhongshi tushuguan guanxun (Taichung Teachers College Quarterly), Vol. 28, 
Internet edition, December 1999. Available at http://lib.ntctc.edu.tw/info/info28/ info28-1.htm

51. "Explanation of the Abolishment of 'Getting to Know Taiwan' Subject", MOE newsletter, October $15^{\text {th }} 2001$.

52. It includes Minnan yu, Hakka dialect, and aborigine languages.

53. According to the Editorial Committee for History Curriculum, the reason for choosing 1500 was because: "it was the beginning of frequent communication between countries... no nation or culture could be isolated from the world". Also, they believed, that the major events that happened in China the after sixteenth century were mostly the result of the interaction with other countries or foreign forces. "Do not Judge the High School History Curriculum With Fixed Ideologies", MOE newsletter, September $23^{\text {rd }} 2003$.

54. “Tu Cheng-sheng's Concentric Circle Theory Emphasises Indigenous Culture and Prioritising Taiwan", Central News Agency, May $19^{\text {th }} 2004$.

55. Wu Chan-liang, "Xia yi dai xuyao shenme yangde shiguan?" (What Kind of Historical View Does the Younger Generation Need?), China Times, Internet edition, September $19^{\text {th }} 2003$.

56. Sung Kuo-cheng, "Zhe jiu shi women yao de bentuhua ma?" (Is This Indigenisation What We Want?), Xin xinwen (New Journalism), Vol. 865, Internet version, October $7^{\text {th }}$, 2003, p.56.

57. "Legislators Clash over High School History Textbooks", Taipei Times, Internet version, October $16^{\text {th }} 2003$.

58. Huang I-ching, "High School New Curricula will be Implemented in 2006 as Planned", Liberty Times, (Internet Version), May $19^{\text {th }} 2004$.

59. "Taiwan guandian ditu xilie, huan ge jiaodu kan Taiwan" (Maps of Taiwanese Perspective: Viewing Taiwan from Different Angles), CCA website, 2004.

60. The English word "TAIWAN" has been added to the cover of all Taiwanese passports since September 2003 to differentiate the Taiwanese from the mainland Chinese.

61. National currency is generally regarded as a symbol of national identity and autonomy. Since 2000, a set of newly designed banknotes has been issued in Taiwan. Although the decision to change the design was made in 1999, the most significant difference was the change of the "issuing bank", from the Bank of Taiwan to the Central Bank of China (Zhongyang yinhang, the bank's own translation). Over the years, several revisions of Article 13 of the 'Central Bank of China Act' were made. The Central Bank had legally been appointed the issuing bank for national currency since 1961, and the New Taiwanese Dollars were regarded "equivalent to national currency" since 1967. However, in order to maintain the image of the ROC representing China, the Central Bank did not issue New Taiwanese Dollars directly, but had entrusted the Bank of Taiwan to issue the currency. When Chen Shui-bian came to power in 2000, the DPP government soon acted to implement Article 13. New Taiwanese Dollars are now issued by the Central Bank of China, and consequently, are the national currency.

62. In recent years, a discourse-Taiwanese aborigines being part of the Austronesian community - has been widely disseminated. Through academic research and official support, this discourse has developed fast. Consequently, the ties between aboriginal peoples of Taiwan, Philippines, Malay, and New Zealand are growing strong.

63. On a visit to Kaohsiung in June 2004, Vice President Annette Lu claimed that the DPP government was considering a relocation of ROC capital to Kaohsiung after 2009. She explained that the South represented the local voice, and the relocation was part of 
the DPP's action to achieve the South Revolution (Nanfang geming). However, Lu's proposal was soon denied by the DPP government. The term "South Revolution" appeared after the 1998 elections, when DPP candidate Chen Shui-bian lost his Mayoral seat in Taipei and KMT candidate Wu Tun-I lost his Mayoral seat in Kaohsiung. Some believed that it was the beginning of a north-south divide. In general, the term "South Revolution" refers to the DPP's goal of diverting power from the Central Government in the North to the South.

64. Since the late 1990s, the dates of national holidays have changed drastically. Since the late 1990s, the KMT government had gradually cancelled several national holidays which were considered politically incorrect or outdated, such as the Youth Day (or Martyrs Day, March $29^{\text {th }}$ ), Taiwan Recovery Day (October $25^{\text {th }}$ ), and Chiang Kai-shek's birthday (October $31^{\mathrm{st}}$ ). After Chen Shui-bian came to power in 2000, the DPP cancelled another two national holidays: Sun Yat-sen's Birthday (November $12^{\text {th }}$ ), and Constitution Day (December $25^{\text {th }}$ ).

65. Tchen Yu-chiou, "New Thoughts on Taiwanese Culture", 2004.

66. Rita Fang, "Fashion Designers Enlisted to Create National Costume", Taiwan Journal, November $15^{\text {th }}-21^{\text {st }} 2003$.

67. Chen Hui-min, "Red Will be our Cultural Colour", Financial Daily News, January $20^{\text {th }}$ 2004.

68. Young Shao-hua, "Taiwan hong, kaifa wuxian wenchuang chanzhi” (Taiwan Red, Developing the Unlimited Industrial Added Value of the Creative Industries), Qian zazhi (Money Magazine), Internet edition, January 2004.

69. Wu Mercy, "CCA Launches Project to Highlight Taiwan", E-Taiwan News, Internet edition, February $19^{\text {th }} 2004$.

70. By May $14^{\text {th }} 2004$, the World Heritage Committee of UNESCO has appointed 754 properties worldwide to the World Heritage List (582 cultural, 149 natural and 23 mixed properties in 178 states). See: UNESCO, World Heritage website. The People's Republic of China has had 30 sites listed, while Taiwan has none. Since 2002, through the recommendation of the local governments and scholars, twelve sites (such as the old mountain railway on the Ali Mountain, Kinmen, and Fort Santo Domingo) were selected by the CCA to propose to the World Heritage Committee "Denglu shijie kanjian Taiwan" (Listed in the World Heritage, Taiwan will be Seen), Internet edition, 2003. http:// wpc.e-info.org.tw/PAGE/DISCUSS/taiwan_heritage.htm

71. Ibid.

72. Taylor Charles, “The Politics of Recognition", in Amy Gutmann (ed.), Multiculturalism and 'The Politics of Recognition': An Essay, New Jersey, Princeton University Press, 1992, p.32.

73. Ibid, p. 34

74. As well as Chinese Minnan and Hakka cultures, the DPP claimed that Taiwanese culture was a mixture of pre-historical, aboriginal, Dutch, Spanish and Japanese cultures. Austronesian culture was identified as the most important dimension of Taiwanese-ness since it would differentiate Taiwan from China. Tourism Bureau, "Ershiyi shiji Taiwan fazhan guanguang xin zhanlüe" (New Strategy for Taiwan Tourism in the $21^{\text {st }}$ Century), available at http://202.39.225.136/auser/b/stratagem/ index.htm

75. Lee Shun-te, "The Ministry of Marine Affairs is Denied, the Councils for Aboriginal and Hakka Affairs are Secured", United Daily News, September $8^{\text {th }} 2004$. 
76. Tchen Yu-chiou claimed that Taiwanese culture was a hybrid mixture of $60 \%$ Chinese culture and 40\% other cultures, including: Austronesian, Japanese, American and western European cultures. Tchen Yu-chiou, talk in Taiwan's Social and Political Landscape Since 2000, SOAS, September $29^{\text {th }} 2004$.

\section{ABSTRACTS}

What triggered the change in Taiwanese identity in the 1990s? How has a sense of Taiwaneseness been constructed since then? How does the state formulate Taiwanese culture and create meaning within that culture? This article looks at how Taiwan's ruling parties have constructed Taiwanese culture and identity since the lifting of martial law. It compares the continuity and differences in cultural policies between two political regimes-the KMT's apparent emphasis on indigenisation and the DPP's push for de-sinification-focusing mainly on the policy of Taiwanisation. 